\title{
Paradigms of the Nations Classification in European and Soviet Marxism
}

\author{
Sergii Rudenko
}

Doctor of Philosophical Sciences, Professor, Guangdong University of Petrochemical Technology (Maoming, China); Taras Shevchenko National University of Kyiv

(Kyiv, Ukraine)

E-mail: rudenkosrg@gmail.com

https://orcid.org/0000-0001-9069-0989

\section{Vyacheslav Vilkov}

Ph.D. (Philosophy), Associate Professor, Taras Shevchenko National University of Kyiv

$$
\text { (Kyiv, Ukraine) }
$$

E-mail: tvvvilkof59@gmail.com

https://orcid.org/0000-0002-3542-0756

Rudenko, Sergii, and Vyacheslav Vilkov (2020). Paradigms of the Nations Classification in European and Soviet Marxism. Ukrainian Policymaker, Volume 6, 2020: 85-103. https:// doi.org/10.29202/up/6/9

For the first time in the post-Soviet period, in a separate publication, prerequisites, key ideas, theoretical, methodological, ideological and political paradigms of nationalities by world and European "classics of Marxism" (Friedrich Engels, Austro-Marxist Otto Bauer, Joseph Stalin and Vladimir Lenin, etc.) are analyzed and revealed in reliance on the principle of historicism and methods of systematic, comparative, discursive and content analysis in political, philosophical and ideological aspects. Comparative research of the interpretations of the main types of nations by the ancestors of Marxism and their theoretical models, and also ideologemes, which were created in Soviet Marxism in the second half of the twentieth century, was carried out.

The material of the article is particularly important for a relevant understanding of the specifics and direction of the development of philosophical and socio-political studies in the USSR and Ukraine in the second half of the 1960s, the second half of the 1980s, and for the scientific understanding of the paradigmatic, analytical and ideological prescriptions of the Marxist-Leninist theory of the nation and the communist meta narration in their confrontation with Western concepts. In the present circumstances, the results of such an analysis are essential for the creation of a correct assessment of the theoretical platform and ideological attitudes of that period Soviet authority in the sphere of national and cultural, national-state and socialist building, as well as its struggle with "bourgeois nationalism."

(C) Rudenko, Sergii, 2020

(C) Vilkov, Vyacheslav, 2020 
Keywords: socio-political studies, USSR and Ukraine, differentiation of nations, Friedrich Engels, Austro-Marxism of Otto Bauer, Stalin's classification of nations, Marxist-Leninist historical and economic theory of the nation, scientific communism

Received: March 6, 2020; accepted: April 21, 2020

\section{Introduction}

It should be noted that the social sciences, especially in the socialist countries and specifically in the Soviet Union, actively carried out ideological functions in the geopolitical situation of the second half of the twentieth century. Using the cliché of that era, they were at the forefront of the ideological struggle between the two political systems and ideological doctrines - Socialist, Soviet, Marxist-Leninist, communist, internationalist, on the one hand, and capitalist (imperialist), anti-communist, anti-Soviet and bourgeois-nationalist, on the other.

Because of this geopolitical and ideological confrontation, one of the key challenges of the theory of the nation for Soviet experts in the field of the theory of the nation (especially in the situation of obvious ethnocultural commonality of the population of some alternative socio-political systems and states, first of all, the GDR and the GFR, the DPRK and the Republic of Korea (South Korea); the activation of national liberation movements in different regions of the world; international recognition of such a politically extraordinary phenomenon as "countries of socialist orientation," with their national or nationalist-oriented leadership and ruling parties, etc.), was the problem of interpreting the relationship of the national liberation struggle of peoples and the struggle for social liberation of the exploited classes, i.e., socialism.

Initially, the only way to solve the problems of the interconnection between national and social liberation was the democratic, proletarian and social revolution, the abolition of capitalist economic and political relations. So, the following model was used: "to the national through social liberation." Nevertheless, Marxists of different countries and of different historical periods were not unanimous about the specific way of implementing the general scheme. Different social democratic and communist leaders preferred (including the theoretical justification, ideological, propagandist, and organizational support, etc.) one of the two versions.

The first version, on which Karl Marx and Friedrich Engels insisted (in work, called The Principles of Communism of 1846, he directly stated that the proletarian/socialist revolution must occur in all capitalist countries simultaneously), later the Trotskyists with their idea of a "permanent revolution" (even in the mid-twentieth century). ${ }^{1}$ Relied on a postulate which read as follows, "Since the position of the workers of all countries is the same, since their interests are the same, and their enemies are the same, they must fight together, and they must oppose the fraternal union of all nations to the bourgeoisie union of all nations" (Engels, 1955: 373). Thus, the solution of the issue of national freedom, independence or statehood of each individual nation, and even the very legitimacy of its struggle for liberation, was made entirely dependent by the founders of Marxism (an exception was made only for Poland

\footnotetext{
${ }^{1}$ For example, Pierre Frank (1905-1984), who was one of the leaders and theorists of the Trotskyist movement of the second half of the twentieth century, a member of the secretariat of the Fourth International (to 1979), a member of the leadership of the international Revolutionary Communist League organization (from 1968 to 1984), explicitly stated that the question of national independence does not constitute any significant part of the theory of the permanent revolution (cited by 984, pp. 56).
} 
and Ireland) and by many of their followers on the tasks and prospects of the international labour movement, on the success of its victory over the power of the international bourgeoisie. Within the framework of such a political approach and ideologeme, many national liberation movements of peoples in Europe were often criticized by Marxists, who considered them to be a hindrance in the revolutionary struggle of the proletariat, and a distraction from the main goal in politics.

The second, which was a historically later version, and was actively developed primarily by the Bolsheviks, especially by Vladimir Lenin since August 1915 (an article headed "On the Slogan of the United States of Europe"), presupposed a social revolution within a separate national state (the unitary or federal state was not important). Nevertheless, even without it, the first step and a huge impetus for the development of the working-class movement was the unconditional right of peoples to self-determination, i.e., the national liberation struggle that could lead to the attainment by a nation of state independence.

On the other hand, the dialectics of Lenin's political thinking was that he believed the right of nations to self-determination and the "freedom of their separation" to be not an end in itself, but a means in the struggle for socialism, as well as a prerequisite and impetus to an alliance of nations in a future regional or world socialist state. Briefly, the argument here is that, firstly, he claims that "any democratic demand (including self-determination) for conscious workers is subject to the highest interests of socialism" (Lenin, 1979: 108). Secondly, "We won't," he stressed, "a free connection, and therefore we must recognize the freedom of separation (without freedom of separation, a connection cannot be free)" (Lenin, 1974b: 379). Therefore, "we" (RSDLP (b)) demand the freedom of self-determination, i.e., independence, i.e., freedom of separation of oppressed nations, not because we have dreamed of economic fragmentation or the ideal of small states, but on the contrary, because we want large states and rapprochement, even a merger of nations, but on a genuinely democratic, genuinely internationalist base, impossible without the freedom of separation. As Marx in 1869 demanded the separation of Ireland not for dividing, but for further free Union of Ireland with England, not "out of a sense of fairness to Ireland," but for the interest of the revolutionary struggle of the English proletariat, so we consider the refusal of the socialists in Russia from the demand of freedom of self-determination of nations, in a sense indicated by us, a direct threat to democracy, internationalism and socialism" (Lenin, 1973a: 68). Thirdly, remaining a supporter of the idea of the world proletarian revolution (which can begin at the first stage in several most developed capitalist countries), and also taking into account the realities of imperialism at the beginning of the twentieth century, the models the process and interaction of its driving forces. "The social revolution," he argues, "cannot happen otherwise than in the form of an era connecting the civil war of the proletariat with the bourgeoisie in the advanced countries and a number of democratic and revolutionary, including national liberation movements in undeveloped, hindward and oppressed nations" (Lenin, 1979: 112). Ideally, the social liberation of the exploited masses and the national liberation of oppressed peoples should result in a unique and global political alliance, namely, the "World Federal Soviet Republic" (Lenin, 1974: 47).

\section{Friedrich Engels's Political and Philosophical Differentiation of Nations}

In the context of the above-described matter, the problem of the typology of nations arose in the Marxist (socialist and communist) movement, which in the course of the complex and 
controversial historical process of the second half of the nineteenth and the first half of the twentieth century, acquired several dimensions or aspects.

Undoubtedly, in the twentieth century for Marxism-Leninism, the model of social-class differentiation of national communities was already prior. The division of nations into "capitalist" and "socialist."

However, in the middle of the nineteenth century, for the founders of the communist doctrine, such a typology had not been of interest yet. Moreover, one should take into account the fact that a clear theoretical vision of the historical destinies of nations after the overthrow of the capitalist system, which was presented by the founders of the communist doctrine as a clear result of the socialist revolution on a global, at least on the European scale, was not formed. In addition, separate and isolated judgments of the authors of the Communist Party Manifesto, where for the first time it was stated that "Workers have no fatherland," do not allow to fully scientifically analyze their point of view on this issue.

Another critical point in the analysis of the ideas about nations of the founders of Marxism (that, by the way, in the German political, philosophical and linguistic tradition used the term "nation" very freely), mainly by Engels, in the publication "Why Does the Working Class Care about Poland?" (1866), was the fact that he (not without the influence of Karl Marx) expressed some ideas and strategic proposals for solving the "national question," which from any socialist or communist positions cannot be called democratic. In fact, the typology of nations, (conceptually similar to the discriminatory version proposed by the liberal J. Stuart Mill), was declared by one of the founders of the communist doctrine and the apostle of the principle of "proletarian internationalism and equality of all nations," according to which all ethnonational communities were divided (supposedly from the principles of "European democracy" and the interests of the "working class") into two types. The first is "large and viable European nations having European importance" and a long political history. According to the logic of the theoretical modeling of Engels, they would also have an unconditional "right to a separate independent existence" in the future, i.e. own national statehood. Engels highlighted such privileged, or according to his words, "The large and well-defined historical nations of Europe," as "Italy, Poland, Germany, Hungary, France, Spain, England, Scandinavia, that have not ever been divided and have not been under foreign domination." He also added Russia to this list, but already "as the owner of an enormous amount of stolen property (nations and ethnic groups included into the empire. - Authors), which it would have to give back on the payback day."

The second type, according to Engels, is a considerable number of "historically unviable nations." He characterized them either as "remnants of peoples" deprived of "vital energy" for their own cultural and political development or as such peoples that became "peripheral parts" of "big nations." These ethnonational "peripheries," the founder of the communist doctrine believed, "joined the national life of some other peoples and no longer want to rejoin their main stem." Engels also added to such historically unpromising politically national formations a "multitude of small nationalities inhabiting South-Eastern Europe." According to his estimates, they did not have European historical and political significance, the democratic right to "political independence" and, therefore, they could not be given their own statehood. For this reason, their further destiny was either to assimilate with the great European nations or to become their peculiar ethnocultural "decoration." The creator of communist ideology as a doctrine of universal liberty and equality offered his recipe for solving the national question in Europe, "In the end, there is a great benefit in the fact that various nations that have been formed politically in most cases contain some foreign elements that create a link with their 
neighbours and introduce diversity into the too monotonous homogeneity of the national character" (Engels, 1960: 160-161).

Being far from the ideals of democracy and internationalism, the understanding of Frederick Engels of the principles of solving the national question and of the "liberation" of oppressed peoples, even in civilized Europe, and respectively, the division of nations into historically "viable" and "not viable," was generally tried not to mention in the publications of the Soviet Marxists ${ }^{2}$.

Moreover, "In 1896, the London Congress of the Second International proclaimed the general democratic demand for self-determination of nations," and in Russia, "on the insistence" of Vladimir Lenin, "the principle of self-determination of nations was included in the RSDLP Program in 1903" (Kaltakhchian, 1983: 222).

Meanwhile, at the beginning of the twentieth century, especially shortly before the First World War, the working-class movement of many European countries, as well as numerous socialist and pro-communist parties in Europe and Russia, with the idea and the general democratic political demand for "freedom of national self-determination," formed a strong and many-sided opposition. "Referring to the progressiveness of large, multinational states," Suren Kaltakhchian, for example, noted, "Right opportunists called for their preservation under any circumstances, and therefore did not support national liberation movements." "The left" opportunists claimed that this right was supposedly impracticable under capitalism, and it was not necessary under socialism" (Kaltakhchian, 1983: 222). At the same time, both "the right" and "the left" opportunists, and even some nationalist parties (in particular, the Bund party in Russia) promoted the project of "cultural ethnic autonomy" as the only correct and effective way of solving the national question, i.e., the elimination of national inequality and discrimination in multinational states, the liberation of all national minorities from cultural and political oppression (even from "everyday nationalism and chauvinism") on the part of the national majority, its economically and politically ruling class.

Also, the Austro-Marxists and the theory of the nation and the project of national autonomy, which, at first glance, seemed to be politically and ideologically harmless, gave rise not only to misperceptions about the essence of the Marxist interpretation of objective logic, stages, forms and driving forces (classes, nations) of world history but created a confrontational ground for intra-party and cross-party disputes (even within the social-democratic movement of one country). They motivated and stimulated endless discussions among the theorists and ideologists of Marxism at the beginning of the twentieth century: on the subject of the strategy and tactics of "ways and means of solving the national question" (for example, in the Russian and Austro-Hungarian empires); "on the attitude to the imperialist war" (chauvinistic support of their national government/state "until its final victory" or, on the contrary, international

${ }^{2}$ In connection with such a clearly undemocratic position of Engels, the leadership of the Soviet propaganda system, in one of the notes to his work, trenched on the sacred - to break all-party canons and to publish in the mildest form, but still, a few critical remarks, "The views of Engels on the historical fate of small peoples, his judgments that they, as a rule, are not capable of independent national existence and inevitably must be assimilated in the course of historical development by larger and more viable nations, were inaccurate". The reason for this is that Engels did not properly take into account one of the "tendencies" "pertained to capitalism" - the struggle of small nations against national oppression for their independence, their desire to create their own statehood. As history has shown, many small nations, and above all the Slavic peoples that were formerly part of the Austrian Empire, not only discovered the ability of independent national development but participated in the creation of a new social and socialist system" (Engels, 1960: 666). 
proletarian class solidarity "for the defeat of their government in the war"; on how to create the international unity of the workers of all countries for the victory of the world socialist revolution. No less sharp disputes flared up between the "Marxists" of Europe and Russia (which were especially actively triggered by the Trotskyists and not only in the USSR) on the subject of the possibility of a victory of the revolution, thus, building socialism already "in one single country." In the USSR, in the 1920s and early 1930s, the problems of the theory and practice of national politics and nation-state building (institutional, economic, cultural, etc.) were added to this complex of irreconcilable discussions.

\section{Otto Bauer's Typology of National Communities}

So, getting back to the theory of the nation of many-sided international Marxism, it should be reminded that the program of "cultural ethnic autonomy" was developed by Austrian Marxists. This political project of "national liberation" was directly based on the axioms of the model of national and nationality, which was proved by the legal expert, Karl Renner and the influential political thinker and activist, Otto Bauer. In addition, the ideas of the latter were of particular importance in the context of the revolutionary struggle for the social liberation of the exploited masses of the working people (i.e., the elimination of capitalism) and ideas of how to understand the future of nations under socialism.

According to Otto Bauer, nations (he believed the German nation to be an ideal model of genesis) are communities of people that appear not so much in the era of the emergence of capitalism, as Karl Marx and Friedrich Engels did, but exist throughout the history of humankind. They are both a class and classless (starting from the primitive communal system or, according to Bauer, "genus communism") society phenomenon. Moreover, Otto Bauer argued that in a society divided into classes, the "commonality of culture" "embraces only the ruling class," whereas "the broad masses, on whose labour this class feeds, are outside this commonality" (Bauer, 1909: 51). These masses "do not constitute nations, since their origin no longer sews them with sufficiently strong threads; do not yet constitute, since the emerging community of upbringing is still not influencing them" (Bauer, 1909: 140). As a result, according to the logic of the primordial interpretation (read, for example, Vilkov, 2014: 6-74) and contrary to the theory of Karl Marx and Friedrich Engels, their Austrian "follower," who even publicly declared himself a "Marxist," posited, "Three different stages in the development of a nation correspond to the three stages of human society development the era of genus communism, the modern class society and the future socialist society" (Bauer, 1909: 139).

Otto Bauer, in addition to the revision of the initial postulates of the socio-philosophical doctrine of Marxism and its historical and materialistic conception of the formation and development of nations, also made a substitution and confusion of the meanings and sense of their primary, systemic concepts. "A nation of class society, divided into members and nonmembers of this nation," he declared, having deprived the Marxist concepts of "communism," "socialism," and "nation" of their specific theoretical and ideological content and connection to the socio-historical era, "is a product of the decomposition of the communist nation of the past and a piece of material for the formation of a socialist nation of the future" (Bauer, 1909: 141). And with regard to the essence of "socialism," the social nature of "socialist nations" and their main tendency of development, he presented an absolutely anti-Marxist, especially from the point of view of Soviet Marxism, formula — "Involvement of the whole people 
in a national cultural community, the acquisition by a nation of its complete identity (not an independent politico-territorial, i.e. not a sovereign national and state entity (even as a part of a federation), but only an extraterritorial cultural, national autonomy in the "state of nationalities" is meant. - Authors), the increasing spiritual differentiation of nations, that is what socialism means" (Bower, 1909: 111).

In general, the assessments of the nature and tendencies of the development of socialist nations made by Otto Bauer, which in fact were declared to be the final type of national formations that are the most comprehensive in world history, turned out to be theoretically, politically and ideologically non-Marxist. Furthermore, they were much less anti-MarxistLeninist.

The substantiation of the fact that there would be no rapprochement between nations under socialism, offered by the ideologue of Austro-Marxism, was of particular political and ideological significance in the context of the ideas of the Otto Bauer's concept of the nation and his project of "cultural national autonomy" as the only supposedly true for socialists (social democrats, communists) final way to solve the "national question" during the transition from capitalism to socialism, and then and under the socialist system. Ethnicity in them (primarily "national character," which, according to Otto Bauer, ensures the reproduction of "common cultural values") is more primary, more fundamental, and stronger than any social-class factor. Therefore, he explained that even after the socialist transformations, after the elimination of the political and legal prerequisites of national inequality and oppression, after the establishment of democratic and internationalist values in the political system, there would inevitably be no active interethnic rapprochement (spiritual, cultural, political) and much less not the origin of the process of "merging of nations," as it was presented to the theorists and ideologists of European Marxism (later to Lenin and his followers in the USSR), but something completely opposite. "Nations," the Austrian Marxist declared categorically, offering his vision of the prospects for their development in the global post-capitalist system, "will once again be sharply differentiated in a socialist society, and a nation will then be the totality of all those people who enjoy national education and will develop under the influence of national destiny" (Bauer, 1909: 140).

Of course, Otto Bauer devoted the main theoretical and ideological attention to the ways of resolving the national question in the bourgeois multinational states, and precisely in AustriaHungary. He did not fundamentally consider and predicted the objective historical and political logic of socialist nation-state building, either "in a single country" or "on a global scale." Moreover, he did not model the future of nations during the transition to a communist society. Thus, unlike Vladimir Lenin, Joseph Stalin, or Karl Kautsky, and after Soviet Marxists, he did not even seek to explain the prerequisites, incentives and conditions for the spiritual and cultural rapprochement of nations in the socialist and, in the long run, communist reality.

On the other hand, at the beginning of the twentieth century, the "doctrine of AustroMarxism" posed a real threat to the revolutionary struggle for power. First of all, it opposed one of the main mobilization slogans of the Russian social democracy - "On the Right of Nations to Self-determination." Therefore, in the publications of their leaders, in the party press, in propaganda and agitation work with the multinational proletarian masses, they constantly and sharply criticized the Austro-Marxist theory of the nation as bourgeois-nationalist, opportunist, and revisionist. Whenever possible, they tried to prove the mistakenness and political harmfulness of the strategy of the project of ethnic, cultural autonomy in the struggle to overthrow the autocracy in Russia and destroy the capitalist system in it, which inevitably 
causes national oppression and discrimination. In short, the Russian Bolsheviks said that, firstly, the ideas and goals of such a project, divided the working class of different nations, and secondly, did not encourage the numerous national liberation movements in the Russian empire to fight together against the existing system, because they were deprived of their "ideal" — the opportunity to get their own national state. And thirdly, they created a false theoretical picture of national building and development of national cultures under socialism.

But in the end, another "irony of history" was that the uncompromising and longstanding struggle of the RSDLP (b) against Austro-Marxism and its followers (including its followers in Russia) became the main cause of its ideological and political collapse. In this case, the decisive role was played not by subjective (personalities, ideas, organizations, etc.), but by objective historical factors, the causal relationships of the world-historical process itself, the logic of global and regional political events of the second decade of the twentieth century. Its essence was that after the proletarian revolution in Russia in November 1917, after the end of the First World War in 1918 and after the collapse of the four empires, including the AustroHungarian one, Austro-Marxism, as a theory of the nation and its project of "cultural national autonomy," lost all ideological and political significance and influence.

Instead, in 1917 and 1918, a political and legal model and ideologeme, called "The Right of Nations to Self-determination", acquired significance (state self-determination). It was proclaimed and began to be practically realized by the Bolsheviks, who gained political power in the vast territory of multinational Russia. To some extent, similar ideas in the same historical period were declared (January 8, 1918, 14 points in the appeal to the US Congress) and then partially realized by the American President Woodrow Wilson. It was achieved with the help of European politicians during the redrawing of borders in Europe and the Ottoman Empire on the basis of the principle of the "legal personality of nations," i.e., according to the model of classical national states.

Meanwhile, the dialectics of history is that, since the 60s of the last century, the theoretical construction of national genesis and national community, similar to the one offered by Bauer, had again begun to gain popularity in the scientific and political circles of Europe. And, accordingly, it demanded a critical reaction from Marxist-Leninists.

In particular, the representative of the West German historical studies, Werner Konze, on the basis of "mixing nationality (ethnic, ethnocultural. — Authors) and nation," absolutization of the "ethnic side of a nation," downplayed "the importance of the decisive economic, social, political and spiritual content of a nation, which was associated with a capitalist or socialist society." Thus, "despite all the historical facts and laws, he "reanimated the concept of the socalled "single stream," i.e., the reproduction of "permanence of the German nation within the framework of three socio-economic formations" (feudalism, capitalism, socialism). Therefore, it was clear that as a result of such an ethnicist and primordial theoretical modelling, Werner Konze, who (as well as the CIA) hardly had a gift of foresight or strategic forecasting (especially because of the collapse of the USSR and the East European socialist economic, military and political bloc (the CMEA and the Warsaw Pact organization), the unification of the GDR and the FRG), actually proposed a historical foundation for combining "two qualitatively different historical types of nations" - "the socialist one and the capitalist German" (Kozing, 1978: 174, 176).

Certainly, for Soviet and German (GDR) politicians, party ideologues and, respectively, the scientific community of social scientists of the pre-perestroika period, a similar (Werner Konze) theoretical construction (even as a mythologeme or ideologeme) was completely 
unacceptable, and for the mass consciousness of citizens of the socialist countries, it was found absolutely inadmissible.

Therefore, at that time, within the framework of the Marxist-Leninist theoretical approach (primarily historical materialism and scientific communism) and the official ideology, statements could only be made on the subject of competition or confrontation between bourgeois nations and national states with each other or with the rest non-capitalist world. And, on the contrary, they could be made about the objective, historically conditioned, and historically inevitable tendency of the rapprochement of socialist nations and strengthening the commonwealth of their state formations.

\section{Joseph Stalin's Classification of Nations}

It should be admitted that in terms of the history of the development of theoretical ideas about the division of nations into bourgeois and socialist, and about the dialectics of the process of flourishing and bringing nations closer under socialism, Soviet Marxist-Leninists (like scientists in socialist countries), in the second half of the twentieth century, formally made reference to the Lenin's ideas and work. At the same time, they carefully avoided the fact that fundamentally and systematically these phenomena and processes were interpreted not by Vladimir Lenin, who was the first head of the Soviet state and the ruling party, but by the second head, i.e., Joseph Stalin (the article "The National Question and Leninism. The Answer to the Comrades Meshkov, Kovalchuk and Others" 1929).

Moreover, by the 1980s, with the active participation of specialists from the socialist countries, a whole interdisciplinary, but independent research direction, had been formed. Its representatives had intensively been working on a conception (including many different applied aspects, problems, questions), the official name of which was The Theory of the Socialist Nation. The number of those who dealt with its theme, as well as the number and nature of publications devoted to certain issues of this theory, goes into infinity. Scientific analysis of this whole complex of information is practically impossible. But it is not needed, because the essence of the approach, which is the indissoluble unity of several basic theoretical and ideological postulates and was called The Theory of Socialist Nation, can fully be displayed and ideologically evaluated by the work of several Soviet "science of nation" authors.

The monograph "Marxist-Leninist Theory of the Nation and Socialist Practice" (1985), by leading Ukrainian researchers Froim Gorovskiy and Yuri Rymarenko, is the most optimal and demonstrative. The essence of the metanarrative of "socialist nation" is revealed by them in the form of a thesis. Firstly, this is the definition of the theoretical model itself, which is formulated in the traditions of the Soviet Marxist-Leninist social and philosophical scholasticism and the strategic prescripts of the communist doctrine. Its definition reads: "The theory of a socialist nation is a scientifically based and practice-proven teaching about laws, concepts and categories that adequately reflect the process of formation, development and mutual enrichment of nations under socialism, its improvement and gradual development into communism, as well as the dialectics of the establishment and complete unity of nations and their merging in the future into an internationally united humanity." Secondly, in general, and global structural terms, "The Theory of the Socialist Nation is an integral part of the Marxist-Leninist teaching with its theory of the socialist revolution, the building of a socialist and communist society." And "in present circumstance" (the second half of the $20^{\text {th }}$ century), this theory "fits organically into the concept of developed, mature socialism" Thirdly, the authors note that, although 
"differentiation of the theory of the socialist nation from the general theory of the nation as an independent object" is "conditional," but "it is still legitimate." Fourthly, as a concept, which has its own object of study, this theory has its own structure. Its "most important components are the doctrine of the laws on the formation of a new type of nations in the process of the socialist reorganization of society, on the trends of their development in the socialist era, on the development of socialist nations into the nations of communist society, the doctrine of international communities, the ways and conditions of the establishment of complete unity of nations and their subsequent merging." Fifthly, "The Theory of the Socialist Nation in all its aspects is creatively developed by the Communist Party of the Soviet Union," The experience of the USSR on "socialist national development" is "summarized in party documents" (in all its structural, republican levels), "constitutions of the Union and autonomous republics", "in the works of Soviet party and state representatives, social scientists, practical workers of the ideological front." "Parties of the friendly Marxist-Leninist countries and Marxist scholars of socialist countries contributed a lot to this experience." Sixthly, that is not an axiom, and therefore allows historical verification and can be scientifically challenged. "V. I. Lenin is the founder of the theory of a socialist nation. In 1916, for the first time in Marxist literature, he used the concept of a "socialist nation" in work called The Results of the Discussion on SelfDetermination. Both in this and in other works V. Lenin reveals the essence of socialist nations, the unity of economic life which is based on public property, deep social cohesion as a result of the elimination of exploitative classes, social firmness with a variety of forms of national cultures" (Gorovskiy \& Rymarenko, 1985: 99-101). At the same time, to confirm the special contribution of Lenin in the creation of the Theory of Socialist Nation, Froim Gorovskiy and Yuri Rimarenko give paginal references to only four of his works from 1916-1920, which were devoted to completely different national problems.

Meanwhile, according to our estimates, the "theory of the socialist nation" is absent in the publications of Lenin, and he (with the exception of the mentioned above "Results of the Discussion on Self-Determination," where he uses the term/phrase "big advanced socialist nations") does not even use this concept.

In his numerous works and published speeches, the leader of the Russian Social Democrats is not talking about socialist nations, but about nations in the conditions of a particular form of socialist statehood. And, as a rule, in a hypothetical prospect, Lenin is interested in the possibility and the need to ensure for all national formations, especially the "long oppressed nations," equality and restoration of historical justice. This, he believed, was possible only in one extremely democratic way, by granting each of the nations complete "freedom of selfdetermination," i.e., the sovereign right to choose the institutional form of its independence. Thus, the "self-determination experience" of a nation can be limited to the creation of autonomy within the framework of a state which has long been deprived of rights, dependent and oppressed. Such "experience" can (on request of workers) become a process of "statebuilding," the building of "one's own" state. All this, the head of the RSDLP (b) claimed, could further lead to the complete elimination of national inequalities and nationalist sentiments, to the formation of interethnic peace and solidarity and, ultimately, as we moved towards communism, would ensure the "rapprochement and merge of nations." Here, in particular, is one of the representative (albeit utopian) statements of Lenin, in which many of his key ideas are concentrated on a wide range of national problems, "By rebuilding capitalism into socialism, the proletariat creates a possibility of the complete elimination of the national oppression; this opportunity will become a reality "only," "only"! with full implementation 
of democracy in all areas, up to the definition of the borders of a state in accordance with the "sympathies" of the population, up to the complete freedom of separation. On this basis, consequently, almost absolute elimination of the slightest national friction, the slightest national mistrust will develop, an accelerated convergence and merging of nations will be created, which will end with the withering away of the state" (Lenin, 1977: 22). But it is still far from the "withering away of the state," i.e., building of a communist society. Therefore, Lenin proposes a federation as a transitional ideal political system and form of government. He says, "Federation is a transitional form to the full unity of the working people of different nations" (Lenin, 1974a: 164). It should be noted that this was implemented during the state transformation of post-revolutionary Russia in the RSFSR (politically and legally the process of transforming Russia in the RSFSR began with the victory of the revolution on November 7, 1917, and ended on July 19, 1918, when the Constitution of the Russian Socialist Federal Soviet Republic came into force) and, partially, during the creation of the USSR.

As an additional argument to the above, it should be stated that even in a small article of 1915 , called "On the Slogan of the United States of Europe," Lenin claimed, "The United States of the World (not Europe) is the state form of unification and freedom of nations that we associate with socialism until the complete victory of communism leads to the final disappearance of any state, including the democratic one" (Lenin, 1977a: 354). In the first Constitution of the Soviet Union, adopted in the final version by the II Congress of Soviets of the Soviet Union on January 31, 1924, the principles of which had become the embodiment of Lenin's ideas, contrary to Stalin's centralist position (he insisted that the republics should enter the Union as autonomy, not as sovereign states), the USSR was created as a structure that would be continuously widened by new socialist republics and would include new socialist nations and nation-states. It was unequivocally written in the Constitution that "access to the Union is open to all socialist Soviet republics, both the existing and those emerging in the future" and a "new union state" (i.e. the USSR) "would serve as a true stronghold against world capitalism and a new decisive step towards the unification of workers of all countries in the World Socialist Soviet Republic (highlighted by the author)" (The Basic Law (Constitution)...).

At the same time, Stalin's article "The National Question and Leninism. The Answer to the Comrades Meshkov, Kovalchuk and Others" (1929) it was this work, where he clearly theoretically stated that "two types of nations" are "known to our history." One of them is the "bourgeois nations," "the fate of such nations is connected with the fate of capitalism." "With the fall of capitalism," "such nations" "must leave the stage" of history (Stalin, 1952: 340, 338). "Other nations are new Soviet nations." "Such nations should be classified as socialist nations. These new nations emerged and developed on the basis of the old, bourgeois nations as a result of the elimination of capitalism through their fundamental transformation in the spirit of socialism "that occurred" after the liquidation of the bourgeoisie and its nationalist parties, after the establishment of the Soviet system." At the same time, "the national cultures of our new Soviet nations are socialist cultures in their content" (Stalin, 1952: 339, 354).

Moreover, Stalin, condemning Karl Kautsky for his apology of the "assimilatory "work" of the Germans in the Czech Republic," as a result of which "the Czechs are almost Germanized" and "as a nation, have no future," and criticizing his opponents for not understanding the essence of national development in one case, precisely, "in the period of the victory of socialism on a global scale," and in the other, "in one country," thus explaining the Leninist idea about the socialist prerequisites of "rapprochement and merging of nations" and the disappearance of linguistic differences between them, specifically noted that "the period of the victory of 
socialism in one country does not provide the conditions necessary for the merger of nations and national languages, but, on the contrary, this period creates a favorable environment for the revival and prosperity of nations that were previously oppressed by tsarist imperialism and now freed by the Soviet revolution from the national oppression" (Stalin, 1952: 345). Offering his own interpretation of Lenin's theoretical assumptions, which became fundamental for the post-Stalin period in the development of the Soviet interpretation of the "Marxist-Leninist conception of the nation and national relations" (this is one of the most common names in the Soviet literature of the "historical and economic theory"), he noted that Lenin, firstly, refers "the disappearance of national differences and the merge of nations, not to the period of the victory of socialism in one country, but exclusively to the period of the dictatorship of the proletariat on a global scale, in other words, to the period when socialism gained its victory in all countries when the foundations of the world socialist economy would already be laid." Secondly, Stalin emphasized that "an attempt to designate the process of disappearance of national differences to the period of the victory of socialism in one country, in our country, Lenin qualifies as an "absurd dream" (Stalin, 1952: 346). On the basis of these messages, Stalin made the following theoretical conclusion and an unambiguous political and ideological directive, "It would be wrong to think that the destruction of national differences and the death of national languages will occur immediately after the defeat of world imperialism at one blow, decreeing from above, so to speak. Trying to merge nations by decreeing from above, by enforcement, would mean playing into the imperialists ' hands, ruining the cause of liberation of nations, and burying the cause of organizing cooperation and brotherhood of nations. Such a policy would be tantamount to the policy of assimilation". However, this policy "is excluded from the arsenal of Marxism-Leninism, as an anti-national policy, counter-revolutionary, as a harmful policy" (Stalin, 1952: 347).

On the basis of a specific historical and social-class understanding of the essence of nations, Stalin also offered strategic recommendations for the conduct of the Soviet national policy in the sphere of intellectual culture. "... It is a mistake to think," he noted, "that the first stage of the period of the world dictatorship of the proletariat will be the beginning of the disappearance of nations and national languages, the beginning of the existence of a single common language. On the contrary, the first stage, during which national oppression will be completely eliminated, will be a stage of growth and prosperity of the previously oppressed nations and national languages, a stage of states 'rise, a stage of liquidation of mutual national distrust, a stage of establishing and strengthening international relations between nations". And now, at the "next stage," Stalin emphasized, "as the single world socialist economy develops, instead of the world capitalist economy and "when the world socialist economic system is sufficiently strengthened, and socialism enters the life of the people, when nations are convinced in the practice of the advantages of a common language over national languages, then national differences and languages will begin to disappear, giving way to a common world language" (Stalin, 1952: 348-349).

In the context of the previously mentioned information, it should be additionally noted that at the end of the 20s of the twentieth century, Stalin, as a political realist, was well aware that "it was still far from the implementation of the dictatorship of the proletariat on a world scale, and especially from the victory of socialism in all countries" (Stalin, 1952: 353). Therefore, in his works and practical solutions he proposed only specific measures for the rapid development of national cultures and languages (creation of schools, press, theatres, cinemas, etc., in the mother language), and also insisted on eliminating in the USSR the 
inequality of national representation (calling it "nationalization" or formation "in terms of "ethnicity") in "all management apparatus, from party and trade union to state and economic ones," which presupposed preferences when appointing members of the national majority in the structures of power and administration. First of all, in the republics of the Soviet Union (Stalin, 1952: 355). In general, at that time, he was not engaged in projecting, fantasizing about how the process of a comprehensive and intensive "development, rapprochement and merge of nations" would take place during the building of communism.

The Soviet Marxist-Leninists did it for him in the "era of stagnation." The best example is a passage from the Philosophical Encyclopedic Dictionary (1983). "Erasing national differences," it claimed, not without pathos, "is a longer process than erasing of class differences. A complete merge of nations will occur in mature communism as a result of their further development and gradual rapprochement in all spheres of life. The Communists are not supporters of eternalizing national differences. They support an objective, progressive process of comprehensive rapprochement of nations, creating the prerequisites for their future merge on the basis of complete voluntariness and democracy. "Basing on the Marxist-Leninist theory, one can foresee that the complete victory of communism throughout the world will create conditions for the merge of nations and all people will belong to the classless and nonnational humanity that has a single economy and a single, and diverse communist culture" (Philosophical Encyclopedic Dictionary, 1983: 418).

\section{The Concepts of "Capitalist" and "Socialist" Nation in the Discourse of Soviet Marxism in the second half of the $20^{\text {th }}$ century}

In general theoretical, political and ideological terms, the Soviet Marxist-Leninist approach and semantic emphasis on the fact that the essence of the national community and its culture is not determined by ethnic factors but by social, and nations as social phenomena are completely dependent on socio-economic and socio-political factors, on the type of socio-economic system (formation) and the political system, was also dominant in the scientific literature of the Soviet period. But such definitions were more suitable not for a social or political and philosophical analysis of the national genesis and the essence of nations, but for a newly created branch which was administratively introduced in the USSR (later in other socialist countries) in social-political researches, and a new obligatory scientific discipline - scientific communism. Its ideological basis was the ideology-driven postulates of the Marxist theory of society, which were the basis for the "historical and economic," or, in the typical cliché of the time, "a genuinely scientific theory of the nation created by K. Marx and F. Engels and developed by V. I. Lenin." And within the framework of such an ideology-driven discursive practice and narrative, more appropriate were the interpretations of the phenomenon of the nation as, for example, in the definition proposed in the collective work, called Communism and the Nation (1985). A nation, the authors emphasized, "is a historical form of a community of people of the capitalist era (the capitalist type of nations) and socialist era (the socialist type of nations), characterized by a stable commonality of economic life, language, territory, and national character, manifested in the characteristics of its culture and way of life. In their social nature, capitalist and socialist nations are fundamentally different from each other" (Communism and Nations, 1985: 17).

There was a unity of opinions in the interpretations of Soviet social scientists of that period, both in relation to the name "socialist nations" and in understanding their essence, 
attributive features that represented a symbiosis of the abstract characteristics of the features of the socialist society itself and the standard Marxist-Leninist concept of the nation. A classic example of the definition can be taken from the textbook on scientific communism. Since in the times of the Soviet Union, educational and scientific reference books (dictionaries, encyclopedias) played the role of an officially approved theoretical and ideological standard of interpretation of any political and social phenomenon or process. Here is one of the examples of such a Soviet Marxist-Leninist classics. "A socialist nation is a new socialist community of people that has grown out of the nation or nationality in the process of eliminating capitalism and the victory of socialism, which preserved certain ethnic features, although it received a qualitatively new development, the political, socio-economic and spiritual life of which was completely changed on socialist and international principles.

The formation of socialist nations is the greatest achievement of socialism.

The socialist nation consists of friendly classes - the workers and the cooperative peasantry, as well as the working intelligentsia. Socialist nations are characterized by a commonality of economic life, goals and interests, unity of worldview and international solidarity.

The economic basis of equality, prosperity and rapprochement of nations is the public property of the production means, the socialist economic system" (Fedoseiev et al., 1981: 308).

Almost the same situation was with the interpretation of what the "capitalist nations" represent. And here the same standard formational and social-class Marxist theoretical and ideological approach dominated, with the obligatory mentioning of the fact that ethnic succession is preserved between nations at the stage of capitalism and socialism since any nation "has ethnic elements."

But at the same time, while characterizing the significant differences between capitalist and national socialist communities, Marxist researchers emphasized in their works that socialist nations are necessarily characterized by unity (economic and social interests, political and legal status in the social structure of society, spiritual culture, the system of basic values, ideologies, etc.). Furthermore, vice versa, the main feature of each of the capitalist nations is the presence of "two nations" within each of them (Glezerman, 1975: 118-119).

Although, it should be noted that the very concept of "two nations" in each nation under capitalism in Soviet Marxism did not receive any theoretical development in the second half of the twentieth century. As a rule, researchers limited themselves to quoting and commenting on one judgment of Friedrich Engels and one postulation of Vladimir Lenin. Friedrich Engels of these was from the early work of the founder of the communist doctrine: "The Situation of the Working Class in England" (written as early as 1844-1845), where he argued that "...it does not come as a surprise that the English working-class over time became a completely different nation than the English bourgeoisie. The bourgeoisie has more in common with all other nations than with the workers who live near it. Workers speak a different dialect, have different ideas and thoughts, different morals and moral principles, different religions and politics than the bourgeoisie. These are two completely different nations, which are just as different from each other as if they belong to different races ..." (Engels, 1955: 356).

The Lenin's axiom, which Soviet researchers used very often and in various contexts, was formulated in Critical Notes on the National Question (1913). It read: "There are two nations in every modern nation ... There are two national cultures in each national culture. There is a Great Russian culture of Purishkeviches, Guchkovs and Struves, but there is also a Great Russian culture characterized by the names of Chernyshevskiy and Plekhanov. There are the same two cultures in Ukraine, as in Germany, France, England, the Jews, etc.” (Lenin, 1973: 129). 
It should be emphasized that the narrative and logic of the new Soviet theoretical and communist ideological attitudes in interpreting the ratio of "ethnic," "ethnicity," "national," "social," "people," and "nation" (first of all, the division of nations into capitalist and socialist) as well as the wording of strategic prescriptions for the democratic national policy and state socialist construction was identical with the ideas of the academician Alfred Kozing from the GDR. He, saying that he agrees "with the point of view" of "nationality being an ethnic characteristic of the nation," expressed by the philosopher Suren Kaltakhchan, who was considered to be one of the leading experts in the "nation theory" in the USSR, and revealing his understanding of the phenomenon and the concept of "nationality" ("national affiliation," "identity"), using the example of the German Alsatians and Lothingians, who became an integral part of the French nation, emphasized that it is, in one case, an "objective characteristic." Unless, of course, "we are talking about national identity in the sense of belonging to a nation as a complex social organism that includes ... of course ethnic identity" and "does not depend on how people determine their affiliation" (national, ethnic).

In the other case, "nationality affiliation/identity" is "only ethnicity belonging to one or another group of population with common ethnic features" (Kozing, 1978: 164-165, 173). And it is in this socio-historical dimension that "ethnic characteristic," ethnic similarity/ community, and "national identity," firstly, "passes from the feudal nationality to the capitalist nation in the process of historical development" (Kozing, 1978: 172-173). Secondly, it is then inherited from the feudal and bourgeois past by socialist nations. In general, the "nationality," as a combination of only ethnic features (including identity which is based on them), claimed the German academic, might be the same, but nations as objective historical communities (even with one ethnic/national identity) are often different. For example, "the German socialist nation in the GDR" and "the German capitalist nation in the FRG" (Kozing, 1978: 75-177).

Against the background of uniformity, theoretical and ideological agreement between the Soviet-era Marxist-Leninists, the question of what notion could be used to designate nations that were formed during the development of society from feudalism to capitalism, and existed within the bourgeois economic and political system became critical. Should they be called "bourgeois" (like Stalin did), or "capitalist," or use these concepts as synonyms?

In the early $1980^{\text {th }}$, Suren Kaltakhchian, a leading Soviet expert in the field of national problems, spoke most sharply on this issue with specific arguments, taking into account the assessments made in 1969 at the International Meeting of Communist and Workers Parties and the specifics of the ideological struggle with the West during the cold war, with criticism of the concept of "bourgeois nation" in the monograph called "Marxist-Leninist theory of the nation and modernity" (1983). He stressed that, firstly, "in recent years," the concept of "militant nationalism" has appeared abroad, whose adherents "insistently propagate the idea of the inevitability of conflicts between "bourgeois nations" and "proletarian nations." Thus, this concept is "directed against the socialism of the working people of different nations, against proletarian internationalism." Secondly, he notes, "In terms of the time when the bourgeoisie, losing its role of the hegemon of a nation, no longer determines its image (especially spiritual) as a whole is not historical, and therefore the use of the term "bourgeois nation" is incorrect. He creates a distorted understanding of a nation." Thirdly, such a concept as the "bourgeois nation" "leaves a lot of ambiguity" and "gives rise to various kinds of speculations." "If the term "bourgeois nation," stresses Suren Kaltakhchian, "means the nation of bourgeois society, this will be true, and we will get an opportunity to study the "two nations" in each nation. If the "bourgeois nation" is understood as the bourgeoisness of the whole nation, then this 
will already be wrong. "In general, the concept of the "bourgeois nation" does not help in the fight against anti-scientific and reactionary concepts. It makes it difficult to ascertain the relationship between national and class communities in an antagonistic society, as well as an understanding of the specifics of socialist nations." As a result, the theoretical verdict of Suren Kaltakhchian holds, "The term "bourgeois nation" should be used only when it is clear from the context that this refers to the genesis of a nation, its connection with capitalist productive relations. In other cases (for example, to characterize the spiritual appearance of a nation), its use is theoretically unjustified and is now practically used by reactionaries" (Kaltakhchian, 1983: 214-217).

Meanwhile, subjecting the concept of "bourgeois nations" to a detailed, concrete historical analysis and negative ideological evaluation and stating that "V.I. Lenin" used the term "capitalist nation" most often (Kaltakhchian, 1983: 215), Suren Kaltakhchian in his monograph did not answer the question of whether it is expedient to use the concept of "capitalist nations" instead of the notion of "bourgeois nations." Despite the persistent trend, i.e., unlike most Marxists of the Soviet period (in the USSR or other socialist countries), he avoided using the monosyllabic concepts of "bourgeois" and "capitalist" nations. Instead, in his works, he preferred a semantic construction of "nations and nationalities of capitalist society."

In the work of the academician of the Academy of Sciences of the GDR, Alfred Kozing, along with the joint opinion, in the context of the paradigm ideas of the Soviet Marxists about the relationship between the social and ethnic, the most generally understood as a "form of the national community," as a "concrete form of its social content" or "social essence" and that a nation, as a historical form of the community of people differs mainly from other large and historical stable forms of communities (social groups) - ethnic groups, nationalities, classes, social strata, castes, ethnic-confessional groups, etc., a rather non-standard social-politicalphilosophical idea for the Soviet Marxism-Leninism was expressed (published in the USSR in 1978). Actively quoting Vladimir Lenin, like all Marxists, he, but in his own way interpreted Lenin's axiom, "Nations are an inevitable product and an inevitable form of the bourgeois era of social development" (Lenin, 1977b: 93), and argued that they (nations) are not just a form of community (collectivity, or a large social group) of people of a certain, post-feudal period of history, but something more. He stressed, "In both socio-economic formations the capitalist and socialist, nations is first and foremost a natural form of the development of society." "A nation is a form of development of social existence that continues to exist even after the liquidation of capitalism and plays an important role in the historical development of society" (Kozing, 1978: 120, 124).

On the assumption of such a general sociological message that equates "community" and "society," but without taking into account the fact that nations are not the only "social product" of social development processes even under capitalism, the German scientist made quite radical theoretical and political (because he did not take into account the institutional aspect of national reality, that is, the forms of state structure existing in the world and the nature of globalization processes) conclusions. He stated that a "bourgeois society naturally develops in a national form," and a "socialist nation" is "a form of development of a socialist society" (Kozing, 1978: 121, 125).

However, such a theoretical novelty remained almost unnoticed among Soviet social scientists and did not affect the process of modernization done by them of the historical and economic, Marxist-Leninist theory of the nation. 


\section{Conclusions}

It should be stressed that the nearly two hundred years genesis of the Marxist theory of society, its structure and historical development, the conceptual ideas of its founders and supporters about the origin, essence, and typology of national communities is a complex and controversial conglomerate of theoretical, political and ideological models.

Within the theory of the nation of Marxism, several stages and paradigms, as the most philosophically grounded and ideologically influential, which are associated with the activities of many political parties and movements, and since the 20 s of the twentieth century some state institutions (power, ideological, scientific, educational), may be highlighted. Historically, as well as from the point of view of influencing the programs and activities of social democratic and communist organizations and the fundamental political processes in different countries of the world in the period of the $1840 \mathrm{~s}-1980 \mathrm{~s}$, the following can be distinguished: the system of political and philosophical ideas about a nation and the ways their liberation by Karl Marx and Friedrich Engels; the theory of the nation and the project of the cultural ethnic autonomy of Austro-Marxism (mainly the works of Otto Bauer and Karl Renner); "The Russian Marxist theory of the nation" (the way Stalin called it. - Authors), which was called the MarxistLeninist theory of the nation and was not only "the further development of Vladimir Lenin's ideas of the founders of Marxism", but also, in its evolution (conceptual and ideological), was provided by the entire scientific community of social scientists in the USSR and other socialist countries in the second half of the last century.

Such paradigms were not purely scientific in their essence and purpose. Therefore, many influential Western scholars, for example, Anthony Smith, say that Marxism (including Soviet Marxism-Leninism) has never had its own theory. From the theoretical and methodological position of scientism, such an assessment is legitimate. However, all Marxists did not strain after pure science. They assessed their own views as "ideological science and scientific ideology." Thus, their interpretations of the phenomenon of the national community were components of more general teachings (philosophical, political, sociological), and in addition, they included valuable and ideological prescripts, as well as political recommendations for solving various social and national problems. The ideological core in Marxism was the problem of finding a solution to the dual issue - the social liberation of classes exploited under capitalism and the liberation of the oppressed nations in the bourgeois political and legal system. Alternatively, in other categories building an effective model and ideologeme that would ensure, firstly, the victory of the proletarian/socialist revolution (i.e., liquidation of the capitalist system, laying the foundations of socialist society), secondly, the maximum success of the national liberation struggle of peoples, the exercise of their right to self-determination.

Depending on the Answer to this question, each of the above paradigms suggested their own projects and created a typology of national communities. In addition to the generally accepted for Marxism division of nations into "oppressed" and "oppressive" (sometimes called "imperialistic"), the understanding of the nature and future of "capitalist" and "socialist" nations by the representatives of different theoretical and ideological approaches in Marxism from the $1840^{\text {th }}-1980^{\text {th }}$ was not consistent. Discussions and disputes were sharp, conflict and continuous. In practical terms, many of their ideas were realized only by the creators and supporters of the theoretical model of the nation and the draft resolution of the national question, which was called Marxist-Leninist. However, in practice, its victory and world-wide historic success proved to be temporary. 
After the collapse of the socialist USSR, as well as the radical change in the political and economic systems in the former socialist countries, the reorganization of the foundations of statehood in them, based on the principles of Western democracy and the restoration of capitalism (for which Western economists offered an ideologically neutral euphemism "market economy"), and the Marxist-Leninist theory of the nation with its basic version of their typology (i.e. "capitalist" and "socialist" dichotomies), have lost their scientific value.

\section{References}

Andropov, Yuriy (1983) The Teachings of Karl Marx and some Issues of Socialist Building in the USSR. Moscow: Political literature publishing house.

Bauer, Otto (1909) The National Question and Social Democracy. St. Petersburg.

Fedoseiev, P., Afanasiev V., Brutenets K. and others (1981) Scientific Communism: A Textbook for Higher Educational Establishments. Vol. 5. Moscow: Politizdat.

Communism and Nations (1985). Moscow: Science.

Criticism of Falsification of National Relations in the USSR (1984). Moscow: Politizdat.

Glezerman, Grigotiy (1975) Classes and Nations. Socialism and Nations. Moscow: Mysl publishing house.: 113-124.

Gorovskiy, Froim and Rimarenko Yuriy (1985) Marxist-Leninist Theory of the Nation and Socialist Practice. Kyiv: Vyshcha shkola.

Engels, Freidrich (1955) About Poland. K. Marx and F. Engels. Collected Works. Second edition, Vol. 4. Moscow: State publishing house of political literature.: 371-373.

Engels, Freidrich (1960) Why Does the Working Class Care about Poland? K. Marx and F. Engels. Set of Works. Second edition, Vol. 16. Moscow: State publishing house of political literature.: 156-166.

Engels, Freidrich (1955) The Position of the Working Class in England. K. Marx and F. Engels. Set of Works. Second edition, Vol. 2. Moscow: State publishing house of political literature.: 231-517.

Kaltakhchian, Suren (1983) Marxist-Leninist theory of the nation and modernity. Moscow: Politizdat.

Kozing, Alfred (1978) A nation in History and Modernity (A research held in connection with the historical-materialistic theory of the nation). Moscow: Progress publishing house.

Lenin, Vladimir (1979) About the Caricature of Marxism. Complete Set of Works. Vol. 30. Moscow: Political Literature Publishing House.: 77-130.

Lenin, Vladimir (1973) Critical Notes on the National Issue. Complete Set of Works. Vol. 24. Moscow: Political literature publishing house.: 113-150.

Lenin, Vladimir (1973) The Revolutionary Proletariat and the Right of Nations to SelfDetermination. Complete Set of Works. Vol. 27. Moscow: Political Literature Publishing House.: 61-68.

Lenin, Vladimir (1974) A letter to the workers and peasants of Ukraine. Complete Set of Works. Vol. 40. Moscow: Political Literature Publishing House.: 41-47.

Lenin, Vladimir (1974) Theses to the II Congress of the Communist International. Complete Set of Works. Vol. 41. Moscow: Political Literature Publishing House.: 159-212.

Lenin, Vladimir (1974) On the Revision of the Party Program. Complete Set of Works. Vol. 34. Moscow: Political Literature Publishing House.: 351-381. 
Lenin, Vladimir (1977) The Results of the Discussion on Self-Determination. Complete Set of Works. Vol. 30. Moscow: Political Literature Publishing House.: 17-58.

Lenin, Vladimir (1977) On the Slogan of the United States of Europe. Complete Set of Works. Vol. 26. Moscow: Political Literature Publishing House.: 351-355.

Lenin, Vladimir (1977) Karl Marx. Complete Set of Works. Vol. 26. Moscow: Political Literature Publishing House.: 43-93.

Philosophical Encyclopedic Dictionary (1983) Ed. by: L.F. Ilichev, P.N. Fedoseiev, S.M. Kovalev, VG Panov. Moscow: Sov. Encyclopedia.

Stalin, Joseph (1952) National Poll and Leninism. Answer to the Comrades Meshkov, Kovalchuk and others. Writings. Vol. 11. Moscow: State Political Literature Publishing House.: 333-355.

The Basic Law (Constitution) of the Union of Soviet Socialist Republics. Accessible online: http://www.eaj http://www.hist.msu.ru/ER/Etext/cnst1924.htm

Vilkov, Vyacheslav (2014) Western Nationology of 20th Century: Conceptual Portraits. History of Nation and Nationalism Theories. Saarbrücken: Lambert Academic Publishing. 